\title{
In vitro Evaluation of Crude Extracts and Isolated Compounds from Goniothalamus rongklanus and Goniothalamus latestigma for Bioactive Properties
}

\author{
Nutthapol Funnimid ${ }^{1}$, Wilart Pompimon ${ }^{1 *}$ and Narong Nuntasaen ${ }^{2}$ \\ ${ }^{1}$ Faculty of Science, Laboratory of Natural Products, Center of Excellence for Innovation in Chemistry, \\ Lampang Rajabhat University, 52100 Lampang, Thailand; Ipru.nutthapolfunnimid@gmail.com, \\ pompimon.wilart@gmail.com \\ ${ }^{2}$ The Forest Herbarium, Department of National Park, Wildlife and Plant Conservation, \\ Ministry of Natural Resources and Environment, 10900 Bangkok, Thailand
}

\begin{abstract}
The genus Goniothalamus belongs to the Annonaceae family. The pure compounds from Goniothalamus rongklanus and Goniothalamus latestigma were isolated by repeated column chromatography. The structures were recognized by NMR spectral methods. The chemical compounds of ethyl acetate extract (EtOAc) from the stems of G. rongklanus were identified as goniotriol (1) and stigmasterol glucoside (2). The EtOAc leaves extract of $G$. latestigma yielded a compound, which was identified as pinocembrin (3). The ethyl acetate (EtOAc) and methanol (MeOH) extract were tested for anti-HIV-1 RT and cytotoxic activities against P-388, KB, HT 29, MCF-7, A 549, ASK and CL cell lines. The EtOAc and MeOH extract of G. rongklanus showed evidence of anti-HIV-1 RT inhibition at 76.44 and $88.48 \%$, respectively. The EtOAc extract of G. rongklanus and $G$. latestigma showed cytotoxic activities on $\mathrm{KB}$ and $\mathrm{HT} 29$ with an $\mathrm{ED}_{50}$ at $<4 \mu \mathrm{g} / \mathrm{mL}$. In addition, antibacterial study on extracts and isolated compounds was also performed. Antibacterial study was evaluated using nine strains (Staphylococcus aureus, Enterobacter aerogenes, Escherichia coli 0157: H7, Escherichia coli (ETEC), Escherichia coli (EPEC), Proteus mirabilis, Salmonella typhimuriam, Shigella flexneri and Vibrio cholera) by Minimum Inhibitory Concentration (MIC) and Minimum Bactericidal Concentration (MBC) method. Goniotriol was the most effective antibacterial with a MIC in the range $<0.16$ $0.6 \mathrm{mg} / \mathrm{mL}$ and $\mathrm{MBC}$ in the range $0.3->5 \mathrm{mg} / \mathrm{mL}$. The antibacterial activity of goniotriol has been reported for the first time.
\end{abstract}

Keywords: Antibacterial Activity, Anti-HIV-1 RT, Cytotoxicity, Goniothalamus rongklanus, Goniothalamus lagestima

\section{Introduction}

The genus Goniothalamus (Annonaceae) include about 185 species, of which 25 species are found in Thailand ${ }^{1}$. This genus is widely distributed in the tropical forests of Southeast Asia and are used in traditional medicine. Root barks of G. cheliensis and seeds of G. amuyon are used in the treatment of edema and arthritis ${ }^{2,3}$. The stem bark of G. laoticus has been applied as roborant ${ }^{4}$.
G. macrophyllus has been used in the treatment of colds, fever, malaria, cholera, to stimulate blood flow in the body and after childbirth ${ }^{5,6}$. This genus has been previously reported for styryl lactones, flavonoids, naphthoquinones, azaanthraquinones, alkaloids, and acetogenins $^{7-11}$. Compounds isolated from Goniothalamus genus has generally shown cytotoxicity, antimycobacterial, antimalarial, antiinflammatory, antitumor, antiviral, anti-larvicidal, anti-biofilm and

\section{*Author for correspondence}


antiplasmodial activity $7,9,12,13$. Styryl lactone compounds are the most isolated compounds from this genus for example, goniothalamin, goniotriol, cardiobutanolide, goniofufurone, altholactone, goniopypyrone, goniodiol, and goniothalamin oxide. Goniothalamin has shown cytotoxicity in oral cavity, breast, small cell lung, and vero cell lines ${ }^{14}$.

G. rongklanus is a member of this genus, locally known as 'Pa-Nan-Rong-Kla' in Thai. This species is distributed in the Northern and North-Eastern Thailand. G. latestigma is locally known as 'Sa-LaoTon' and distributed around Peninsular Thailand. These species are small trees upto $8 \mathrm{~m}$ tall and slender, featured by flowers with whorl of three sepals and two whorls of three petals each, the inside petals are connivant and forming a distinctive dome over the stamens ${ }^{1}$.

There are no reports related to isolation of compounds from G. rongklanus and G. latestigma and their bioactive evaluation. Hence, the study was planned to extract, isolate, characterize the compounds from $G$. rongklanus and G. latestigma and to evaluate them for Anti-HIV-1 RT (Reverse Transcriptase), cytotoxicity and antibacterial activity.

\section{Materials and Methods}

\subsection{Plant Materials}

The stems of G. rongklanus (BKF. 152884) were collected from Phuhin Rongkhla National Park, Amphoe Nakhonthai, Phitsanulok Province, Northern Thailand in 2017. The leaves of G. latestigma (BKF. 163333) were collected from Surat Thani provinces, Thailand in 2017. The plant materials were authenticated by Narong Nantasean, The Forest Herbarium, Ministry of Natural Resources and Environment, Bangkok.

\subsection{General Procedures}

${ }^{1} \mathrm{H}(500 \mathrm{MHz}),{ }^{13} \mathrm{C}(125 \mathrm{MHz})$ and 2D NMR spectra were noted on a BrÜker AV-500 spectrometer in deuterated chloroform $\left(\mathrm{CDCl}_{3}\right)$ and deuterated methanol $\left(\mathrm{CD}_{3} \mathrm{OD}\right)$ solutions. The tetramethylsilane (TMS) was internal standard of chemical shifts $(\delta)$ in ppm. The mass spectra were recorded on a Thermo Finnigan Polaris
Q mass spectrometer at $70 \mathrm{eV}$ (probe) and EIMS were measured by a BrÜker Esquire apparatus. Infrared spectra (IR) were recorded at potassium bromide (KBr) solid with a Shimadzu 8900 FT-IR spectrophotometer and major bands $\left(\lambda_{\max }\right)$ were noted in wave number $\left(\mathrm{cm}^{-1}\right)$. The Column Chromatography (CC) were used silica gel $60 \mathrm{H}$ from E. Merck. 70-230 mesh ASTM, cat. No. 7734 and Sephadex LH-20 $(20-150 \mu \mathrm{m})$ for absorbents. Thin layer chromatography (TLC) technique was proceeded on silica gel 60 PF254 at aluminium sheets and isolated compounds were described below ultraviolet light. Melting points were defined by a Büchi 322 micro melting point apparatus and records in degree Celsius $\left({ }^{\circ} \mathrm{C}\right)$.

\subsection{Extraction and Isolation}

\subsubsection{Isolation of Chemical Constituents from G. rongklanus Extracts}

The air-dried milled stems of G. rongklanus (1.772 $\mathrm{kg})$ was extracted with EtOAc $(6 \times 5 \mathrm{~L})$ (ethyl acetate) and $\mathrm{MeOH}(6 \times 5 \mathrm{~L})($ methanol) at room temperature for three days to yield EtOAc extract (47.98 g) and $\mathrm{MeOH}$ extract (103.86 g) after solvent removal by rotary evaporator.

The EtOAc extract was isolated to pure compounds by $\mathrm{CC}$ with gradient mixtures of Hexane: EtOAc (100:0-0:100) followed by mixtures EtOAc: $\mathrm{MeOH}$ $(100: 0-0: 100)$ to give 8 fractions $\left(A_{1}-A_{8}\right)$ which was characterized by TLC. Fraction $\mathrm{A}_{7}(8.04 \mathrm{~g})$ was further subjected to $\mathrm{CC}$ to furnish 5 subfraction $\left(\mathrm{B}_{1}-\mathrm{B}_{5}\right)$. Subfraction $\mathrm{B}_{3}(0.48 \mathrm{~g})$ was crystallized by $95 \%$ ethanol to yield yellow needles of compound 1 (0.3 g).

Subfraction $\mathrm{B}_{4}(1.70 \mathrm{~g})$ was separated on CC by eluting with gradient mixtures of Hexane: EtOAc (100:0-0:100) followed by mixtures EtOAc: $\mathrm{MeOH}$ (100:0-0:100) to provide 4 fractions $\left(\mathrm{C}_{1}-\mathrm{C}_{4}\right)$. Subfraction $\mathrm{C}_{3}$ and $\mathrm{C}_{4}$ showed similar TLC characteristic therefore it was combined and then further purified by flash column chromatography (FCC) with gradient mixtures of Hexane: EtOAc (100:0-0:100) followed by mixtures EtOAc: $\mathrm{MeOH}$ (100:0-0:100) to give 3 fractions $\left(\mathrm{D}_{1}-\mathrm{D}_{3}\right)$ followed by crystallization of $\mathrm{D}_{2}$ in $\mathrm{MeOH}: \mathrm{CH}_{2} \mathrm{Cl}_{2}$ (1:1) to yield compound 2 (0.02 g) as white solid. 


\subsubsection{Isolation of Chemical Constituents from G. latestigma Extracts}

The air-dried milled leaves of G. latestigma (1.035 $\mathrm{kg})$ was extracted with EtOAc $(6 \times 5 \mathrm{~L})$ and $\mathrm{MeOH}$ $(6 \times 5 \mathrm{~L})$ at room temperature for three days to yield EtOAc extract $(46.55 \mathrm{~g})$ and $\mathrm{MeOH}$ extract $(60.69 \mathrm{~g})$ after solvent removal by rotary evaporator.

The EtOAc extract was separated by CC with gradient mixtures of Hexane: EtOAc (100:0-0:100) followed by mixtures EtOAc: $\mathrm{MeOH}$ (100:0-0:100) to yield 7 fractions $\left(\mathrm{E}_{1}-\mathrm{E}_{7}\right)$ which was characterized by TLC. Fraction $\mathrm{E}_{3}$ $(9.09 \mathrm{~g})$ was further subjected to column chromatography to give 5 subfraction $\left(F_{1}-F_{5}\right)$. Subfraction $F_{2}(0.72 \mathrm{~g})$ was subjected to CC by eluting with Hexane: EtOAc (100:00:100) and then with mixtures EtOAc: $\mathrm{MeOH}$ (100:0$0: 100)$ to obtain 3 fractions $\left(G_{1}-G_{3}\right)$. The $G_{2}(0.57 \mathrm{~g})$ was recrystallized by $95 \%$ ethanol to yield compound 3 $(0.44 \mathrm{~g})$ as pale needles.

\subsection{Anti-HIV-1 RT (Reverse Transcriptase) Assay}

The extracts of G. rongklanus and G. latestigma were tested for anti-HIV-1 RT assay and cytotoxicity at the Service Centre of Department of Microbiology, Mahidol University, Thailand. The anti-HIV activities were determined by testing $\mathrm{RT}$ inhibition ${ }^{15,16}$. The extracts were dissolved in $20 \mathrm{mg} / \mathrm{mL}$ of 100\% dimethyl sulfoxide (DMSO) after removal of tannin by Polyvinylpyrrolidone (PVP). The final volume was 200 $\mu \mathrm{g} / \mathrm{mL}$ in $10 \%$ DMSO and Nevirapine, $2 \mu \mathrm{g} / \mathrm{mL}$ was used as positive control. The HIV-1 RT (Amersham Pharmacia Biotech Asia Pacific Ltd., Hong Kong) kit was used. The 96well plate $(100 \mathrm{U} / \mu \mathrm{l}, 4 \mu \mathrm{l} /$ well $)$ was filled with samples (2 $\mu \mathrm{l} / \mathrm{well})$ and then $2.5 \mu \mathrm{g} / \mu \mathrm{L}$ of poly A and $0.125 \mu \mathrm{g} / \mathrm{mL}$ of oligo dT16 primer was added to $4 \mu \mathrm{l} /$ well and incubated at $37^{\circ} \mathrm{C}$ for $20 \mathrm{~min}$. The reaction was fixed by $0.2 \mathrm{M}$ EDTA $(2 \mu \mathrm{l} /$ well $)$ and incubated at $4{ }^{\circ} \mathrm{C}$ for $15 \mathrm{~min}$. The signal of fluorescence was measurement at emission wavelength of $535 \mathrm{~nm}$ and excitation wavelength of $480 \mathrm{~nm}$ after Pico green dissolved in TE buffer (1: 2000) was added (volume $200 \mu \mathrm{l} /$ well). The results were calculated as percentage of inhibition.

\subsection{Cytotoxicity Assay}

The extracts of G. rongklanus and G. latestigma were also studied for cytotoxicity, using the standard Sulforhodamine B (SRB) assay. Ellipticine was used as the positive control ${ }^{15,17}$. The concentration of the samples was $20-0.16 \mu \mathrm{g} / \mathrm{mL}$ in $0.5 \% \mathrm{DMSO}$. The cancer cell lines used were Murine lymphocytic leukemia (P-388), Human oral cavity carcinoma (KB), Human colon adenocarcinoma (HT 29), Human breast adenocarcinoma (MCF-7), Human lung, adenocarcinoma (A 549), Rat glioma cell (ASK) and Chang liver (CL). MEM (minimum essential medium with Earles salt and L-glutamine) in 10\% FBS were used for culturing of cell lines. The cell lines were maintained $\mathrm{t} 37^{\circ} \mathrm{C}$ for 72 hours (48 hours for P-388) in $5 \% \mathrm{CO}_{2}$ and $100 \%$ relative humidity, followed by stabilizing with $20 \%$ trichloroacetic acid at $4{ }^{\circ} \mathrm{C}$ for 60 min and then stained for $30 \mathrm{~min}$ by $0.4 \%$ SRB in $1 \%$ acetic acid at room temperature. The unbound dye was washed by $1 \%$ acetic acid, already dried stain was mixed with $10 \mathrm{mM}$ Tris base with $\mathrm{pH}=10$. The absorbance was read at $510 \mathrm{~nm}$ on a microplate reader and $50 \%$ effective dose $\left(\mathrm{ED}_{50}\right)$ was calculated.

\subsection{Bacterial Strains}

In vitro antibacterial studies were carried out against nine strains (Staphylococcus aureus ATCC 25923 DMST 8840, Enterobacter aerogenes ATCC13048 DMST 8841, Escherichia coli 0157 : H7 DMST 12743, Escherichia coli (Enterotoxigenic, ETEC) DMST 30543, Escherichia coli (Enteropathogenic, EPEC) DMST 30546, Proteus mirabilis DMST 8212, Salmonella typhimuriam ATCC 13311 DMST 562, Shigella flexneri DMST 4423 and Vibrio cholera nonO1/nonO139 DMST 2873) which were obtained from Department of Medical Sciences, Ministry of Public Health, Bangkok, Thailand.

\subsection{Minimum Inhibitory Concentration $(\mathrm{MIC})^{18}$}

The samples were dissolved in $10 \%$ DMSO to obtain concentrations of $200 \mathrm{mg} / \mathrm{mL}$ (extracts), $5 \mathrm{mg} / \mathrm{mL}$ (isolated compounds) and $1 \mathrm{mg} / \mathrm{mL}$ (chloramphenicol). The extracts and isolated compounds were diluted further 2-fold dilution to a final concentration of 6.25 $\mathrm{mg} / \mathrm{mL}$ and $0.16 \mathrm{mg} / \mathrm{mL}$ for extracts and isolated compounds respectively. The final concentration of $S$. aureus, E. aerogenes, E. coli 0157 : H7, E. coli (ETEC), E. coli (EPEC), P. mirabilis, S typhimuriam, S. flexneri and $V$. cholera in Mueller Hinton Broth (MHB) were $1 \times 10^{6} \mathrm{cfu} / \mathrm{mL}, 50 \mu \mathrm{l} /$ well (Mcfarland standard no. 0.5 ) 
in a 96-well plate and were mixed into the samples (50 $\mu \mathrm{l} /$ well). The plates were incubated at $37^{\circ} \mathrm{C}$ for 24 hours and the growth of organisms were investigated by the color change of resazurin $(1 \mathrm{mg} / \mathrm{mL}, 20 \mu \mathrm{l} /$ well). No colour change indicated the prevention of microbial growth.

\subsection{Minimum Bactericidal Concentration (MBC)}

The MBC assay was determined for samples which did not showed any visible growth and was subsequently sub-cultured on to nutrient agar plate. These plates were incubated at $37^{\circ} \mathrm{C}$ for 24 hours. $\mathrm{MBC}$ was recorded only for the lowest concentration of the bacteria that did not retrieve or a single colony. ${ }^{18}$

\section{Results}

\subsection{Goniotriol (1)}

Yellow needles (ethanol). $\mathrm{C}_{13} \mathrm{H}_{14} \mathrm{O}_{5}$, m.p. = $174.4-175.7$ ${ }^{\circ} \mathrm{C}$, EI-MS $(\mathrm{m} / \mathrm{z}) 250[\mathrm{M}]^{+}(42), 233$ (100), 215 (75), 144 (18), 126 (38), 107 (45), 105 (22), 100 (24), 97 (81), 91 (37), 81 (27), 79 (83), 77 (91), 69 (21), 55 (34). IR (KBr) $\lambda_{\max } 3465(\mathrm{O}-\mathrm{H}), 1718(\mathrm{C}=\mathrm{O}), 2800-2900(\mathrm{C}-\mathrm{H})$, 1637, 1500 and $1450(\mathrm{C}=\mathrm{C}) \mathrm{cm}^{-1} .{ }^{1} \mathrm{H}$ NMR $\left(\mathrm{CD}_{3} \mathrm{OD}\right.$, $500 \mathrm{MHz}): \delta 7.49\left(2 \mathrm{H}, \mathrm{m}, \mathrm{H}-2^{\prime}, 6^{\prime}\right), 7.37$ (2H, m, H-3', 5'), $7.31\left(1 \mathrm{H}, \mathrm{m}, \mathrm{H}-4^{\prime}\right), 7.04(1 \mathrm{H}, \mathrm{dd}, J=9.7,5.7 \mathrm{~Hz}$, $\mathrm{H}-4), 6.11(1 \mathrm{H}, \mathrm{d}, J=9.7 \mathrm{~Hz}, \mathrm{H}-3), 4.77(1 \mathrm{H}, \mathrm{d}, J=7.9$ $\mathrm{Hz}, \mathrm{H}-8), 4.62(1 \mathrm{H}, \mathrm{m}, \mathrm{H}-6), 4.46(1 \mathrm{H}, \mathrm{dd}, J=5.7,3$ $\mathrm{Hz}, \mathrm{H}-5), 4.21$ (1H, dd, $J=7.9,3.8 \mathrm{~Hz}, \mathrm{H}-7) .{ }^{13} \mathrm{C}$ NMR $\left(\mathrm{CD}_{3} \mathrm{OD}, 125 \mathrm{MHz}\right): \delta 164.66(\mathrm{C}-2), 145.03$ (C-4), 141.94 (C-1'), 127.77 (C-3', 5'), 127.43 (C-2', 6'), 127.36 (C-4'), 121.57 (C-3), 78.88 (C-6), 74.24 (C-7), 72.55 (C8), 62.10 (C-5). HMBC correlations, H/C: 7.49 (H-2', 6')/C-1', 2', 3', 4', 5', 6', 8; 7.37 (H-3', 5')/ C-1', 2', 3', 4', 5', 6'; 7.31 (H-4')/C-2', 3', 5', 6'; 7.04 (H-4)/C-2, 3, 5, 6; 6.11 (H-3)/C-2, 4, 5; 4.77 (H-8)/C-6, 7, 1', 2'; 4.62 (H-6)/C-2, 4, 5, 7, 8; 4.46 (H-5)/C-3, 4, 6; 4.21 (H-7)/C-5, 6, 8, 1'. COSY correlations, $\mathrm{H} / \mathrm{H}: 3 / 4,4 / 5,5 / 6,6 / 7,7 / 8,2^{\prime} / 3^{\prime}$, 3’/4', 4’/5', 5’/6' (Figure 1).

\subsection{Stigmasterol Glucoside (2)}

White solid $\left(\mathrm{CH}_{2} \mathrm{Cl}_{2}: \mathrm{MeOH}\right) . \mathrm{C}_{35} \mathrm{H}_{60} \mathrm{O}_{6}$, m.p. $=290.6-$ $291.1{ }^{\circ} \mathrm{C}$, EI-MS $(\mathrm{m} / z) 574[\mathrm{M}]^{+}, 126$ (100), $112(28), 95$
(12), 81 (22), 72 (88), 59 (75), 55 (93). IR (KBr) $\lambda_{\max } 3338$ $(\mathrm{O}-\mathrm{H}), 2868,2933(\mathrm{C}-\mathrm{H}), 1589$ and $1400(\mathrm{C}=\mathrm{C}) \mathrm{cm}^{-1}$ ${ }^{19}$. The ${ }^{13} \mathrm{C}$ NMR $\left(\mathrm{CD}_{3} \mathrm{OD}: \mathrm{CDCl}_{3}, 125 \mathrm{MHz}\right): \delta 140.34$ (C-5), 138.27 (C-22), 129.26 (C-23), 121.97 (C-6), 101.07 (C-1'), 79.16 (C-3), 76.42 (C-3'), 75.96 (C-5'), 73.49 (C-2'), 69.84 (C-4'), 61.23 (C-6’), 56.73 (C-14), 56.02 (C-17), 50.19 (C-24), 45.85 (C-9), 42.27 (C-13), 40.44 (C-20), 39.73 (C-4), 39.66 (C-20), 38.54 (C-12), 37.20 (C-1), 36.63 (C-10), 33.89 (C-7), 31.85 (C-25), 29.44 (C-2, 8), 28.13 (C-16), 24.17 (C-28), 23.00 (C-15), 20.99 (C-11), 19.53 (C-21), 19.08 (C-26), 18.78 (C-27), 18.59 (C-19), 11.71 (C-29), 11.66 (C-18). The ${ }^{13} \mathrm{C}$ NMR spectral data was compared with literature ${ }^{19}$ (Figure 1).
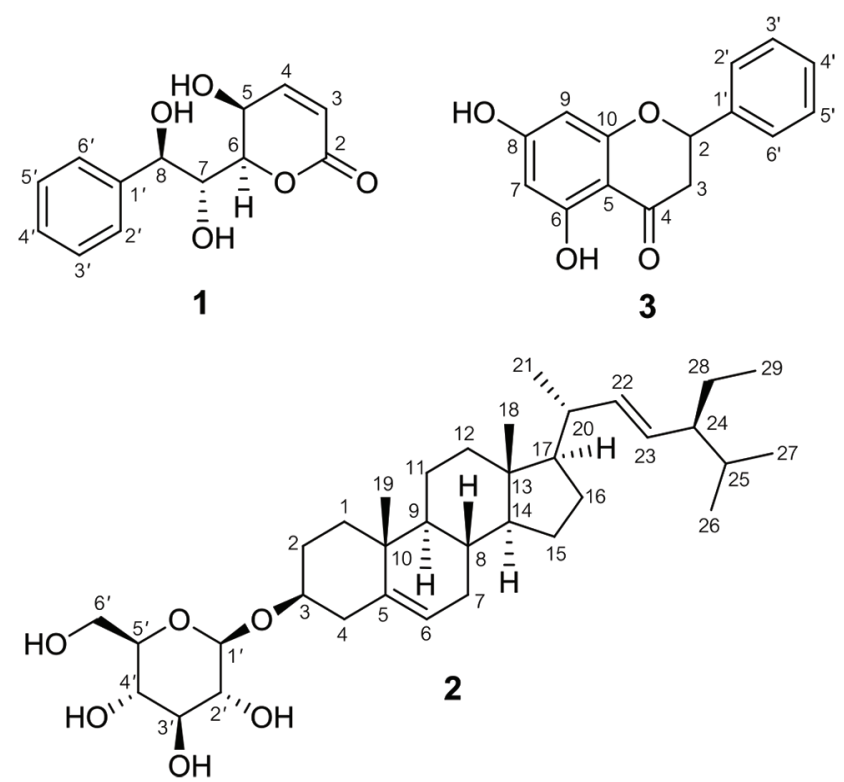

Figure 1. Chemical structures of compounds 1-3

\subsection{Pinocembrin (3)}

Pale needles (EtOAc: $\mathrm{MeOH}$ ). $\mathrm{C}_{15} \mathrm{H}_{12} \mathrm{O}_{4}$, m.p. $=195.9$ -196.5 ${ }^{\circ} \mathrm{C}$, EI-MS $(\mathrm{m} / z) 256[\mathrm{M}]^{+}(86), 257(100), 255$ (58), 179 (36). IR (KBr) $\lambda_{\max } 3406(\mathrm{O}-\mathrm{H}), 1631(\mathrm{C}=\mathrm{O})$, 1436, 1463 and 1487 ( $\mathrm{C}=\mathrm{C}$ of aromatic) $\mathrm{cm}^{-1} \cdot{ }^{1} \mathrm{H}$ NMR $\left(\mathrm{CDCl}_{3}, 500 \mathrm{MHz}\right): \delta 12.06(1 \mathrm{H}, \mathrm{s}, 5-\mathrm{OH}), 7.45(5 \mathrm{H}, \mathrm{m}$, H-2', 3', 4', 5', 6'), $6.04(2 \mathrm{H}, \mathrm{d}, J=1.8 \mathrm{~Hz}, \mathrm{H}-7,9), 5.45$ $(1 \mathrm{H}, \mathrm{dd}, J=13.0,3.1 \mathrm{~Hz}, \mathrm{H}-2), 3.11(1 \mathrm{H}, \mathrm{dd}, J=17.2$, $13.0 \mathrm{~Hz}, \mathrm{H}-3 \mathrm{a}), 2.85$ (1H, dd, $J=17.2,3.1 \mathrm{~Hz}, \mathrm{H}-3 \mathrm{~b}) .{ }^{13} \mathrm{C}$ $\operatorname{NMR}\left(\mathrm{CDCl}_{3}, 125 \mathrm{MHz}\right): \delta 195.76(\mathrm{C}-4), 164.81$ (C-8), 164.34 (C-6), 163.16 (C-10), 138.31 (C-1'), 128.88 (C-3', 5'), 128.87 (C-4'), 126.12 (C-2', 6'), 103.17 (C-5), 96.78 (C-7), 95.52 (C-9), 79.20 (C-2), 43.31 (C-3). НMBC correlations, H/C: 7.45 (H-2', 3', 4', 5', 6’)/C-2, 2', 3', 4', 
$5^{\prime}, 6^{\prime} ; 6.04(\mathrm{H}-7,9) / \mathrm{C}-4,5,6,7,8,9 ; 5.45(\mathrm{H}-2) / \mathrm{C}-4,1^{\prime}, 2^{\prime}$, 6'; $3.11(\mathrm{H}-3 \mathrm{a}) / \mathrm{C}-2,4,1$ '; $2.85(\mathrm{H}-3 \mathrm{~b}) / \mathrm{C}-4,5,1$ '. COSY correlations, $\mathrm{H} / \mathrm{H}: 2 / 3 \mathrm{a}, 2 / 3 \mathrm{~b}, 3 \mathrm{a} / 3 \mathrm{~b}$ (Figure 1 ).

\subsection{Biological Activities}

The bioactivities screening of EtOAc and $\mathrm{MeOH}$ extract of $G$. rongklanus and G. latestigma comprised of anti-HIV-1 RT and cytotoxicity assay on P-388, KB, HT 29, MCF-7, A 549, ASK and CL cell lines. The results are shown in Table 1.

The extract and isolated compounds were studied for antibacterial activity against nine bacterial by micro well dilution assay. The tested concentrations of the extracts ranged between $6.25-200 \mathrm{mg} / \mathrm{mL}$ and $0.16-5 \mathrm{mg} / \mathrm{mL}$ for isolated compounds. The MIC and MBC of samples are shown in Table 2.

\section{Discussion}

Compound (1) (a styryllactone) and (2) (a steroid glucoside) isolated from EtOAc stem extract of G. rongklanus were identified as goniotriol ${ }^{20}$ and stigmasterol glucoside ${ }^{19}$ respectively. Compound (3) (a flavanone) isolated from EtOAc leaves extract of $G$. latestigma was identified as pinocembrin ${ }^{21}$ based on Mass, NMR spectra and analogy with literature data.

Table 1. Anti-HIV-1 RT and cytotoxicity study of crude extracts of G. rongklanus and G. latestigma

\begin{tabular}{|c|c|c|c|c|c|c|c|c|}
\hline \multirow{2}{*}{ Crude extract } & \multirow{2}{*}{$\begin{array}{l}\text { Anti-HIV-1 RT } \\
\text { (\% inhibition) }\end{array}$} & \multicolumn{7}{|c|}{ Cytotoxicity ED E0 $_{50}(\mu \mathrm{g} / \mathrm{mL})^{\mathrm{b}}$} \\
\hline & & P-388 & KB & HT 29 & MCF-7 & A 549 & ASK & CL \\
\hline EtOAc extract of G. rongklanus & 76.44 & 4.59 & $<4$ & $<4$ & 7.11 & 6.82 & 4.82 & 8.19 \\
\hline $\mathrm{MeOH}$ extract of $\mathrm{G}$. rongklanus & 88.48 & - & - & - & - & - & - & - \\
\hline EtOAc extract of $G$. latestigma & 45.75 & 3.99 & $<4$ & $<4$ & 6.83 & 7.23 & 8.54 & 8.16 \\
\hline $\mathrm{MeOH}$ extract of $\mathrm{G}$. latestigma & 18.03 & - & - & - & - & - & - & - \\
\hline Ellipticine (positive control) & - & 0.47 & 0.55 & 0.63 & 0.51 & 0.57 & 0.68 & 0.53 \\
\hline
\end{tabular}

${ }^{*}$ a Anti-HIV-1RT activity express as $\%$ inhibition at $200 \mu \mathrm{g} / \mathrm{mL}$ (radioactive) or $667 \mu \mathrm{g} / \mathrm{mL}$ (non-radioactive): very active $=>70 \%$ inhibition, moderately active $=50 \%$ to $69 \%$ inhibition, weakly active $=30 \%$ to $50 \%$ inhibition and inactive $=<30 \%$ inhibition ${ }^{*}$ C Cytotoxic assay: $\mathrm{ED}_{50}$ less than $20 \mu \mathrm{g} / \mathrm{mL}$ were considered active for extracts. P-388: Murine lymphocytic leukemia, $\mathrm{KB}$ : human oral cavity carcinoma, HT 29: human colon adenocarcinoma, MCF-7: human breast adenocarcinoma, A 549: human lung adenocarcinoma, ASK: Rat glioma cell, and CL: Chang Liver

Table 2. Determination of MIC and MBC for crude extracts and isolated compounds from G. rongklanus and G. Iatestigma

\begin{tabular}{|c|c|c|c|c|c|c|c|c|}
\hline \multirow[b]{2}{*}{ Organism } & \multicolumn{8}{|c|}{ Concentrations of $\mathrm{MIC} / \mathrm{MBC}(\mathrm{mg} / \mathrm{mL})$} \\
\hline & $\begin{array}{c}\text { Gonio } \\
\text { triol } \\
\text { (1) }\end{array}$ & $\begin{array}{c}\text { Stigmas } \\
\text { terol } \\
\text { glucoside } \\
(2)\end{array}$ & $\begin{array}{c}\text { Pinocem } \\
\text { brin } \\
\text { (3) }\end{array}$ & $\begin{array}{l}\text { EtOAc extract } \\
\text { G. rongklanus }\end{array}$ & $\begin{array}{c}\text { MeOH } \\
\text { extract G. } \\
\text { rongklanus. }\end{array}$ & $\begin{array}{c}\text { EtOAc } \\
\text { extract } \\
\text { G. latestigma }\end{array}$ & $\begin{array}{c}\text { MeOH extract } \\
\text { G. latestigma }\end{array}$ & $\begin{array}{l}\text { Chloramp } \\
\text { henicol }\end{array}$ \\
\hline S. aureus & $0.3 / 0.3$ & - & $5 / 5$ & $<6.25 /<6.25$ & $12.5 / 50$ & $<6.26 /<6.25$ & $50 / 200$ & $<0.03 /<0.03$ \\
\hline E. aerogenes & $0.6 / 2.5$ & - & - & $12.5 />200$ & $100 />200$ & $200 />200$ & $200 />200$ & $<0.03 /<0.03$ \\
\hline E. coli 0157:H7 & $0.3 />5$ & - & $5 />5$ & $<6.25 / 200$ & $50 />200$ & $100 />200$ & $100 />200$ & $<0.03 /<0.03$ \\
\hline E. coli (ETEC) & $0.3 / 2.5$ & - & - & $12.5 / 25$ & $100 />200$ & $200 />200$ & $100 />200$ & $<0.03 /<0.03$ \\
\hline E. coli (EPEC) & $0.3 / 1.25$ & - & - & $12.5 / 200$ & $25 />200$ & $200 />200$ & $100 />200$ & $<0.03 /<0.03$ \\
\hline P. mirabilis & $0.3 />5$ & - & - & $<6.25 / 200$ & $200 />200$ & $100 />200$ & $200 />200$ & $<0.03 /<0.03$ \\
\hline S. typhimuriam & $<0.16 />5$ & - & - & $<6.25 / 200$ & $25 />200$ & $50 />200$ & $200 />200$ & $<0.03 /<0.03$ \\
\hline S. flexneri & $0.3 />5$ & - & $5 />5$ & $<6.25 / 25$ & $12.5 />200$ & $50 />200$ & $100 />200$ & $<0.03 /<0.03$ \\
\hline V. cholera & $0.3 />5$ & - & $5 />5$ & - & $100 />200$ & $50 />200$ & $200 />200$ & $<0.03 /<0.03$ \\
\hline
\end{tabular}


Compound 1 was isolated as pale-yellow needles with a melting point of $174.4-175.7^{\circ} \mathrm{C}$. The molecular formula was $\mathrm{C}_{13} \mathrm{H}_{14} \mathrm{O}_{5}$ as analyzed from the molecular ion peak at $m / z 250$ of EI-MS. The ${ }^{1} \mathrm{H}$ NMR spectral data of compound 1 showed resonances at $\delta 7.49(2 \mathrm{H}), 7.37$ $(2 \mathrm{H}), 7.31(1 \mathrm{H}), 7.04(1 \mathrm{H}), 6.11(1 \mathrm{H}), 4.77(1 \mathrm{H}), 4.62$ $(1 \mathrm{H}), 4.46(1 \mathrm{H})$ and $4.21(1 \mathrm{H})$ which was of signals for five protons on aromatic, two protons of conjugated ester carbonyl, and four oxygenated methine proton. The ${ }^{13} \mathrm{C}$ NMR spectral data showed eleven carbons resonances, which were defined to a one carbonyl of ester at $\delta 164.66$, one quaternary aromatic carbon atoms at $\delta 141.94$, three aromatic carbon atoms at $\delta 127.77,127.43$ and 127.36, two methine carbon atoms at $\delta 121.57$ and 145.03 , one oxymethine carbon atoms at $\delta 78.88$ and three secondary alcohol carbon atoms at $\delta 74.24,72.55$ and 62.10, respectively. The NMR spectral data from compound 1 were conforming goniotriol structure in literature.

Compound 2 was obtained as a white solid with m.p. $290.6-291.1{ }^{\circ} \mathrm{C}$. The molecular formula was $\mathrm{C}_{35} \mathrm{H}_{60} \mathrm{O}_{6}$ as analyzed from the molecular ion peak at $m / z 574$ of EI-MS. In comparison of ${ }^{13} \mathrm{C}$-NMR with literature ${ }^{19}$ suggested that the compound $\mathbf{2}$ is a stigmasterol glucoside as it showed resonances of glucoside at $\delta 101.07\left(\mathrm{C}-1^{\prime}\right), 73.49\left(\mathrm{C}^{\prime} 2^{\prime}\right), 76.42$ (C-3'), 69.84 (C-4'), 75.96 (C-5'), and 61.23 (C-6') together with endo cyclic double bond in stigmasterol at $\delta 140.34$ (C-5) and 121.97 (C-6). The ${ }^{13} \mathrm{C}-\mathrm{NMR}$ spectrum presented thirty-five carbons resonances. The DEPT NMR spectrum showed six methyl, ten methylene, sixteen methane, and three quaternary carbons. In comparison with the ${ }^{13} \mathrm{C}-\mathrm{NMR}$ of literature data compound $\mathbf{2}$ was confirmed as stigmasterol glucoside.

Compound 3 was obtained as pale needles with m.p. 195.9 - $196.5^{\circ} \mathrm{C}$. The molecular formula was $\mathrm{C}_{15} \mathrm{H}_{12} \mathrm{O}_{4}$ as analyzed from the molecular ion peak at $m / z 256$ of EIMS. The ${ }^{1} \mathrm{H}$ NMR spectral data of compound 3 showed resonances at $\delta 12.06(\mathrm{OH}), 7.45(5 \mathrm{H}), 6.04(2 \mathrm{H}), 5.45$ $(1 \mathrm{H}), 3.11(1 \mathrm{H})$ and $2.85(1 \mathrm{H})$, which was of signals for one hydroxyl proton, seven protons on aromatic, one oxymethine proton and two proton on position 3 . The ${ }^{13} \mathrm{C}$ NMR spectral data of compound 3 showed thirteen carbons resonances, which were defined to a ketone carbonyl at $\delta 195.76$, three oxygenated carbon atoms at $\delta$ $164.81,164.34$ and 163.16, five aromatic carbon atoms at $\delta 128.88,128.87,126.12,96.78$ and 95.52 , two quaternary aromatic carbon atoms at $\delta 138.31$ and 103.17 , one methylene at $\delta 43.31$ and one oxymethine carbon atoms at $\delta$ 79.20. The NMR spectral data of compound 3 were in consistence with pinocembrin.

The EtOAc and $\mathrm{MeOH}$ extract of G. rongklanus and $G$. latestigma were tested for anti-HIV-1 RT and cytotoxicity on P-388, KB, HT29, MCF-7, A 549, ASK and CL cell lines. The EtOAc and $\mathrm{MeOH}$ extract from G. rongklanus showed very active \% inhibition of 76.44 and 88.48 , respectively. The EtOAc extract of $G$. rongklanus displayed highly potent cytotoxicity against KB, HT 29 and inhibited P-388, MCF7, A 549, ASK and CL cell lines with an $\mathrm{ED}_{50}$ values of $<4$, $<4,4.59,7.11,6.82,4.82$ and $8.19 \mu \mathrm{g} / \mathrm{mL}$, respectively. In addition, the EtOAc extract from G. latestigma showed highly potent cytotoxicity against KB, HT 29 and inhibited P-388, MCF-7, A 549, ASK and CL cell lines with an $\mathrm{ED}_{50}$ values of $<4,<4,3.99,6.83,7.23,8.54$ and $8.16 \mu \mathrm{g} / \mathrm{mL}$, respectively. (Table 1 )

Inhibitory effects of the compound $\mathbf{1}$ was bactericidal with MIC values falling in the range $<0.16-0.6 \mathrm{mg} / \mathrm{mL}$ and $\mathrm{MBC}$ values falling in the range $0.3->5 \mathrm{mg} / \mathrm{mL}$. The crude extracts of both the plants showed the inhibitory effect in the range of values $\mathrm{MIC} / \mathrm{MBC}$ at $<6.25->200 \mathrm{mg} / \mathrm{mL}$, of which the EtOAc extract of $G$. rongklanus was had the best inhibition effect compared to other extracts. (Table 2).

\section{Conclusion}

Crude extracts of G. rongklanus and G. latestigma yielded three compounds which were identified as goniotriol (1), stigmasterol glucoside (2) and pinocembrin (3). Extracts of G. rongklanus showed effective activity in anti-HIV-1 RT assay. Extracts of G. rongklanus and G. latestigma were cytotoxic against KB and HT 29 cell lines. Goniotriol showed potent antibacterial activity against all tested micro-organisms.

\section{Acknowledgement}

Financial support from the Center of Excellence for Innovation in Chemistry (PERCH-CIC), Ministry of Higher Education, Science, Research and Innovation is gratefully acknowledged. 


\section{References}

1. Saunders RM, Chalermglin P. A synopsis of Goniothalamus species (Annonaceae) in Thailand, with descriptions of three new species. Botanical Journal of the Linnean Society. 2008; 156(3):355-84. https://doi.org/10.1111/j.1095-8339.2007.00762.x

2. Jiang MM, Feng YF, Gao H, Zhang X, Tang JS, Yao XS. Three new bis styryllactones from Goniothalamus cheliensis. Fitoterapia. 2011; 82(4):524-7. https://doi.org/10.1016/j.fitote.2010.11.014. PMid:21075179

3. Li X, Chang CJ. Antitumor cytotoxicity and stereochemistry of polyketides from Goniothalamus amuyon. Natural Product Letters. 1996; 8(3):207-15. https://doi.org/10.1080/10575 639608044895

4. The National Identity Office. The National Identity Office, Endemic and Rare Plants of Thailand, Bangkok. 2000; 50-1.

5. Wattanapiromsakul C, Wangsintaweekul B, Sangprapan P, Itharat A, Keawpradub N. Goniothalamin, a cytotoxic compound, isolated from Goniothalamus macrophyllus (Blume) Hook. f. \& Thomson var. macrophyllus. Songklanakarin Journal of Science and Technology. 2005; 27(2):479-87.

6. AbdullahN,Sahibul-AnwarH,IderisS,HasudaT,Hitotsuyanagi Y, Takeya K, Diederich M, Choo CY. Goniolandrene A and B from Goniothalamus macrophyllus. Fitoterapia. 2013; 88:1-6. https://doi.org/10.1016/j.fitote.2013.03.028. PMid:23570840

7. Wiart C. Goniothalamus species: a source of drugs for the treatment of cancers and bacterial infections. Evidence-based Complementary and Alternative Medicine. 2007; 4(3):299311. https://doi.org/10.1093/ecam/nem009. PMid:17965760. PMCid:PMC1978243

8. Choo CY, Abdullah N, Diederich M. Cytotoxic activity and mechanism of action of metabolites from the Goniothalamus genus. Phytochemistry Reviews. 2014; 13(4):835-51. https://doi.org/10.1007/s11101-014-9372-2.

9. Iqbal E, Lim LB, Salim KA, Faizi S, Ahmed A, Mohamed AJ. Isolation and characterization of aristolactam alkaloids from the stem bark of Goniothalamus velutinus (Airy Shaw) and their biological activities. Journal of King Saud University-Science. 2018; 30(1):41-8. https://doi.org/10.1016/j.jksus.2016.12.008

10. Thanuphol P, Asami Y, Shiomi K, Wongnoppavich A, Tuchinda P, Soonthornchareonnon N. Marcanine G, a new cytotoxic 1-azaanthraquinone from the stem bark of Goniothalamus marcanii Craib. Natural product research. 2018; 32(14):1682-9. https://doi.org/10.1080/14786419.2017.1396588. PMid:29098873

11. Rasol NE, Ahmad FB, Lim XY, Chung FFL, Leong CO, Mai CW, Ismail NH. Cytotoxic lactam and naphthoquinone alkaloids from roots of Goniothalamus lanceolatus Miq. Phytochemistry Letters. 2018; 24: 51-5. https://doi.org/10.1016/j.phytol.2018.01.009
12. Lekphrom R, Kanokmedhakul S, Kanokmedhakul K. Bioactive styryllactones and alkaloid from flowers of Goniothalamus laoticus. Journal of Ethnopharmacology. 2009; 125(1):47-50. https://doi.org/10.1016/j.jep.2009.06.023. PMid:19573585

13. Prawat U, Chaimanee S, Butsuri A, Salae AW, Tuntiwachwuttikul P. Bioactive styryllactones, two new naphthoquinones, and one new styryllactone, and other constituents from Goniothalamus scortechinii. Phytochemistry Letters. 2012; 5(3):529-34. https:// doi.org/10.1016/j.phytol.2012.05.007

14. Suchaichit N, Kanokmedhakul K, Panthama N, Poopasit K, Moosophon P, Kanokmedhakul S. A 2H-tetrahydropyran derivative and bioactive constituents from the bark of Goniothalamus elegants Ast. Fitoterapia. 2015; 103: 206-12. https://doi.org/10.1016/j.fitote.2015.04.005. PMid:25865074

15. Reutrakul V, Anantachoke N, Pohmakotr M, Jaipetch T, Sophasan S, Yoosook C, Kasisit J, Napaswat C, Santisuk T, Tuchinda P. Cytotoxic and anti-HIV-1 caged xanthones from the resin and fruits of Garcinia hanburyi. Planta Medica. 2007; 73(01):33-40. https://doi.org/10.1055/s-2006-951748. PMid:17117343

16. Chailungka A, Junpirom T, Pompimon W, Nuntasaen N, Meepowpan P. Two flavonoids first isolated from the seed of Syzygium nervosum and preliminary study of their anticancer and anti-HIV-1 reverse transcriptase activities. Maejo International Journal of Science and Technology. 2017; 11(01):58-67.

17. Thiplueang C, Punyanitya S, Udomputtimekakul P, Buayairaksa M, Nuntasaen N, Banjerdpongchai R, Wudtiwai B, Pompimon W. Sawtehtetronenin and its cytotoxicity from Goniothalamus sawtehii. Natural Products Communication. 2014; 9(12):176971. https://doi.org/10.1177/1934578X1400901228

18. Nath K, Talukdar AD, Bhattacharya MK, Bhowmik D, Chetri S, Choudhury D, Mitra A, Bhattacharjee A. Antibacterial activity of certain ferns against multi drug resistant organisms. Journal of Natural Remedies. 2018; 17(4):144-53. https://doi. org $/ 10.18311 / \mathrm{jnr} / 2017 / 15758$

19. Khatun M, Billah M, Quader MA. Sterols and sterol glucoside from Phyllanthus species. Dhaka University Journal of Science. 2012; 60(1):5-10. https://doi.org/10.3329/dujs.v60i1.10327

20. Abdullah A, Zakaria Z, Ahmad FB, Mat-Salleh K, Din LB. Chemical constituents from the fruit peel of goniothalamus scortechinii. Sains Malaysiana. 2009; 38(3):365-9.

21. Napal GND, Carpinella MC, Palacios SM. Antifeedant activity of ethanolic extract from Flourensia oolepis and isolation of pinocembrin as its active principle compound. Bioresource Technology. 2009; 100(14):3669-73. https://doi. org/10.1016/j.biortech.2009.02.050. PMid:19342224 